\title{
PENGARUH PENGALAMAN KERJA, OTONOMI KERJA, DAN TEKANAN PERAN TERHADAP KINERJA AUDITOR PADA KANTOR AKUNTAN PUBLIK DI BANDAR LAMPUNG
}

(Study Kasus pada Kantor Akuntan Publik di Bandar Lampung)

\author{
Yunus Fiscal , Universitas Bandar Lampung \\ Syilvya, Universitas Bandar Lampung \\ Muh. Nur Ram'dhan, Universitas Bandar Lampung
}

\begin{abstract}
Public Accounting Firm (KAP) is a form of organization that has licensed public accountant in accordance with legislation that seeks the provision of professional services in the field of public accounting practice. CPAs function as an external audit will be effective and optimal performance if supported by auditors. To improve the performance of an auditor, not only requires only intellectual, but also needed a good work experience, freedom and independence in carrying out the duties and powers of office for each professional.

Method of data collection is by using questionnaires distributed to the auditor in public accounting firm in Bandar Lampung, while the analytical tools used are qualitative analysis and quantitative analysis. The results showed that work experience and job autonomy positive and significant impact on the performance of auditors, while the role of pressure and a significant negative effect on the performance of auditors. Based on the above conclusion, it is suggested that public accounting firm auditors to limit the amount of workload and provide clear information to avoid conflicts and role.
\end{abstract}

Keywords : Working Experience, Working Autonomy, Performance Of Auditor's

\section{LATAR BELAKANG}

Profesi akuntan publik merupakan suatu pekerjaan yang berlandaskan pada pengetahuan yang kompleks dan hanya dapat dilakukan oleh individu dengan kemampuan dan latar belakang pendidikan tertentu. Salah satu tugas akuntan publik dalam menjalankan profesinya adalah menyediakan informasi yang berguna bagi publik untuk pengambilan keputusan ekonomi. Profesi akuntan publik merupakan profesi yang unik.

Setiawan dan Ghozali (2006) menyatakan bahwa pada umumnya profesional (contoh: pengacara dan dokter) sebagai pihak pertama, bekerja untuk kepentingan klien yang merupakan pihak kedua (pemohon jasa). Profesi akuntan publik bukan saja dituntut untuk melayani klien (pihak kedua), tetapi lebih mengutamakan tanggung jawab kepada masyarakat (pihak ketiga). Oleh sebab itu, akuntan publik diharapkan mampu menjalankan tanggung jawab yang ada dalam profesinya serta harus bersifat independen dan berkomitmen secara eksplisit melayani kepentingan publik. Maraknya skandal keuangan yang terjadi baik di dalam maupun di luar negeri telah memberikan dampak negatif kepercayaan publik terhadap profesi akuntan publik. Beberapa skandal keuangan yang terjadi di luar negeri seperti Enron, Tyco, Global Crosing, dan Worldcom ternyata melibatkan akuntan publik. 
Sebagai perusahaan yang bergerak di bidang jasa, aset utama yang harus dimiliki oleh sebuah kantor akuntan publik (KAP) adalah tenaga kerja profesional. Agar dapat bertanggung jawab pada publik, para auditor harus berupaya untuk meningkatkan kinerja dalam menjalankan profesinya. Tercapainya kinerja yang baik tidak terlepas dari kualitas sumber daya manusia (SDM) yang baik pula. Terkait dengan peningkatan kinerja profesional, karakter pribadi profesional dan kondisi tempat profesional bekerja menjadi konsekuensi penting bagi KAP, bagi profesional itu sendiri, dan bagi pihak-pihak yang menggunakan jasa profesional (publik). Beberapa karakter pribadi dan kondisi kerja professional dapat menghasilkan tingkat kinerja yang berbeda, keadaan psikologis yang berbeda, dan juga dapat mempengaruhi keputusan profesional untuk tetap atau meninggalkan KAP.

Dalam penelitian Haynes et al, (1998) yang menyelidiki pengaruh peran auditor dalam melayani kepentingan klien menemukan bahwa auditor tidak secara otomatis mengambil posisi advokasi bagi klien, terutama bila kepentingan klien tidak dibuat eksplisit. Tetapi bila kepentingan itu ditonjolkan, auditor khususnya yang berpengalaman kerja akan berperilaku konsisten dengan posisi advokasi.

Pengalaman kerja dipandang sebagai faktor penting dalam memprediksi dan menilai kinerja auditor dalam melakukan pemeriksaan. Tirta dan Sholihin (2004) menyatakan bahwa pengalaman yang dimiliki auditor akan membantu auditor dalam meningkatkan pengetahuannya mengenai kekeliruan dan kecurangan. Auditor yang berpengalaman adalah auditor yang mampu mendeteksi, memahami dan bahkan mencari penyebab dari munculnya kecurangan-kecurangan tersebut, sehingga kualitas audit yang dihasilkan akan lebih baik daripada auditor yang tidak berpengalaman. Secara umum orang berpendapat bahwa jika seseorang dihadapkan pada tuntutan pekerjaan yang melampaui kemampuan individu tersebut, maka dikatakan bahwa individu itu mengalami stres kerja atau tekanan peran dalam pekerjaan. Tuntutan-tuntutan pekerjaan pada auditor dapat megakibatkan stress kerja pada auditor.

Menurut Philip L. Rice dalam Amilin dan Rosita (2008), seseorang dapat dikategorikan mengalami tekanan peran atau stres kerja jika urusan stres yang dialami melibatkan juga pihak organisasi atau perusahaan tepat individu bekerja. Stres kerja juga dapat ditimbulkan akibat adanya terjadinya tekanan peran dikarenakan adanya ketidakseimbangan antara karakteristik kepribadian auditor dengan karakteristik aspek-aspek pekerjaannya dan dapat terjadi pada semua kondisi pekerjaan. Tekanan peran dapat menimbulkan ketegangan dalam bekerja, ketidakpuasan kerja, kecenderungan meninggalkan perusahaan, dan kinerja yang buruk.

\section{TELAAH LITERATUR DAN PENGEMBANGAN HIPOTENSI}

\subsection{Pengertian Otonomi Kerja (Job Autonomy)}

Otonomi kerja (job autonomy) merupakan tingkat kebebasan, independensi, dan kebijaksanaan yang dimiliki seseorang dalam merencanakan suatu pekerjaan dan menentukan cara apa yang digunakan untuk melaksanakan pekerjaan tersebut. Astriana (2010) mengembangkan tiga skala penilaian aspek otonomi:

a. Work method autonomy merupakan kemampuan seseorang memilih cara apa yang digunakan untuk menyelesaikan suatu pekerjaan.

b. Work schedule autonomy merupakan kemampuan seseorang mengatur rangkaian penyelesaian tugas. 
c. Work criteria autonomy merupakan kemampuan seseorang menyediakan sumber daya yang dibutuhkan untuk evaluasi.

Dalam penelitian ini, penilaian aspek otonomi fokus pada keputusan (judgment) profesional daripada aspek-aspek teknis seperti penjadwalan kerja dan tugas-tugas administrasi lainnya. Otonomi juga berkaitan dengan kemampuan profesional untuk menentukan dan meregulasi aturan yang berhubungan dengan profesinya. Sebagai auditor senior dalam perusahaan, mereka diberikan lebih banyak tanggung jawab dan kontrol pada pekerjaan mereka dan pekerjaan bawahan.

\subsection{Tekanan Peran (Role Stress)}

\subsubsection{Pengertian Tekanan Peran (Role Stress)}

Pengertian stres dengan tekanan peran (role stress) adalah sama, hanya saja ruang lingkup untuk pengertian stres jauh lebih luas, karena bisa terjadi dan disebabkan oleh lingkungan kerja maupun di luar lingkungan kerja, sedangkan stres kerja hanya terjadi di lingkungan kerja (Gibson, 1991). Tekanan peran (role stress) merupakan fenomena psikologis, di mana terdapat ketidakseimbangan antara tuntutan dalam pekerjaan dan kemampuan individu untuk mengatasi tuntutan tersebut. Reaksi orang dapat berbeda-beda dalam menghadapi sumber stres yang sama, hal ini disebabkan karena adanya perbedaan individual yang memungkinkan sebagian orang tidak mengalami stres kerja dan sebagian lainnya mengalami stres kerja (Robbins dalam Desiana, 2003).

Gibson, et al. (dalam Yulianti, 2000:9) mengemukakan bahwa tekanan peran (role stress) dikonseptualisasi dari beberapa titik pandang, yaitu stres sebagai stimulus, stres sebagai respon dan stres sebagai stimulus-respon. Stres sebagai stimulus merupakan pendekatan yang menitikberatkan pada lingkungan. Definisi stimulus memandang stres sebagai suatu kekuatan yang menekan individu untuk memberikan tanggapan terhadap stresor. Pendekatan ini memandang stres sebagai konsekuensi dari interaksi antara stimulus lingkungan dengan respon individu. Pendekatan stimulus-respon mendefinisikan stres sebagai konsekuensi dari interaksi antara stimulus lingkungan dengan respon individu. Stres dipandang tidak sekedar sebuah stimulus atau respon, melainkan stres merupakan hasil interaksi.

Tekanan peran terdiri dari tiga dimensi:

1) Kelebihan beban kerja (role overload) merupakan kondisi dimana pegawai memiliki terlalu banyak pekerjaan yang harus dikerjakan atau di bawah tekanan jadwal waktu yang ketat. Overload dapat dibedakan secara kuantitatif dan kualitatif. Dikatakan overload secara kuantitatif jika banyaknya pekerjaan yang ditargetkan melebihi kapasitas karyawan tersebut. Akibatnya karyawan tersebut mudah lelah dan berada dalam tegangan tinggi. Overload secara kualitatif bila pekerjaan tersebut sangat kompleks dan sulit sehingga menyita kemampuan karyawan.

2) Konflik peran (role conflict), terjadi ketika berbagai macam pegawai memiliki tugas dan tanggung jawab yang saling bertentangan satu dengan yang lainnya. Konflik ini juga terjadi ketika karyawan diperintahkan untuk melakukan sesuatu tugas/pekerjaan yang berlawanan dengan hati nurani atau moral yang mereka anut.

3) Keambiguitasan peran (role ambiguity), adalah tidak adanya pengertian atau ketidakjelasan dari seseorang tentang hak, hak khusus dan kewajiban- kewajiban dalam mengerjakan suatu pekerjaan. Oleh karena karyawan tidak mampu untuk menentukan secara tepat apa yang diminta organisasi dari mereka, maka mereka terus-menerus merasa cemas apakah kinerja mereka telah cukup atau belum. 


\subsubsection{Faktor-faktor yang Mempengaruhi Tekanan Peran}

Kondisi-kondisi yang cenderung menyebabkan tekanan atau stres disebut stressors. Meskipun tekanan dapat diakibatkan oleh hanya satu stressors, biasanya karyawan mengalami tekanan karena kombinasi stressors. Menurut Robbins (2001:565-567) ada tiga sumber utama yang dapat menyebabkan timbulnya tekanan yaitu :

(1) Faktor Lingkungan

Keadaan lingkungan yang tidak menentu akan dapat menyebabkan pengaruh pembentukan struktur organisasi yang tidak sehat terhadap karyawan. Dalam faktor lingkungan terdapat tiga hal yang dapat menimbulkan tekanan bagi karyawan yaitu ekonomi, politik dan teknologi. Perubahan yang sangat cepat karena adanya penyesuaian terhadap ketiga hal tersebut membuat seseorang mengalami ancaman terkena stress. Hal ini dapat terjadi, misalnya perubahan teknologi yang begitu cepat.

(2) Faktor Organisasi

Didalam organisasi terdapat beberapa faktor yang dapat menimbulkan tekanan yaitu role demands, interpersonal demands, organizational structure dan organizational leadership. Pengertian dari masing-masing faktor organisasi tersebut adalah sebagai berikut :

a. Role Demands, peraturan dan tuntutan dalam pekerjaan yang tidak jelas dalam suatu organisasi akan mempengaruhi peranan seorang karyawan untuk memberikan hasil akhir yang ingin dicapai bersama dalam suatu organisasi tersebut.

b. Interpersonal Demands, mendefinisikan tekanan yang diciptakan oleh karyawan lainnya dalam organisasi. Hubungan komunikasi yang tidak jelas antara karyawan satu dengan karyawan lainnya akan dapat menyeba bkan komunikasi yang tidak sehat. Sehingga pemenuhan kebutuhan dalam organisasi terutama yang berkaitan dengan kehidupan sosial akan menghambat perkembangan sikap dan pemikiran antara karyawan yang satu dengan karyawan lainnya.

c. Organizational Structure, mendefinisikan tingkat perbedaan dalam organisasi dimana keputusan tersebut dibuat dan jika terjadi ketidakjelasan dalam struktur pembuat keputusan atau peraturan maka akan dapat mempengaruhi kinerja seorang karyawan dalam organisasi.

d. Organizational Leadership, berkaitan dengan peran yang akan dilakukan oleh seorang pimpinan dalam suatu organisasi. Karakteristik pemimpin menurut The Michigan group (Robbins, 2001:316) dibagi dua yaitu karakteristik pemimpin yang lebih mengutamakan atau menekankan pada hubungan yang secara langsung antara pemimpin dengan karyawannya serta karakteristik pemimpin yang hanya mengutamakan atau menekankan pada hal pekerjaan saja.

(3) Faktor Individu

Pada dasarnya, faktor yang terkait dalam hal ini muncul dari dalam keluarga, masalah ekonomi pribadi dan karakteristik pribadi dari keturunan. Hubungan pribadi antara keluarga yang kurang baik akan menimbulkan akibat pada pekerjaan yang akan dilakukan karena akibat tersebut dapat terbawa dalam pekerjaan seseorang. Sedangkan masalah ekonomi tergantung dari bagaimana seseorang tersebut dapat menghasilkan penghasilan yang cukup bagi kebutuhan keluarga serta dapat menjalankan keuangan tersebut dengan seperlunya. Karakteristik pribadi dari keturunan bagi tiap individu yang dapat menimbulkan stress terletak pada watak dasar alami yang dimiliki oleh seseorang tersebut. Sehingga untuk itu, gejala stres yang timbul pada tiap-tiap pekerjaan harus diatur dengan benar dalam kepribadian seseorang. 


\subsection{Kinerja (Job Performance)}

\subsubsection{Pengertian Kinerja (Job Performance)}

Kinerja (job performance) dalam Bahasa Indonesia beasal dari kata dasar "kerja" yang menerjemahkan dari bahasa asing prestasi, bisa pula hasil kerja. Pengertian kinerja dalam organisasi merupakan jawaban dari berhasil atau tidaknya tujuan organisasi yang telah diterapkan. Para atasan atau manajer sering tidak memperhatikan kecuali sudah amat buruk. Kesan-kesan buruk organisasi yang mendalam berakibat dan mengabaikan tanda-tanda peringatan adanya kinerja yang merosot. Kinerja menurut Anwar Prabu Mangkunegara (2000:67) adalah hasil kerja secara kualitas dan kuantitas yang dicapai oleh seseorang pegawai dalam melaksanakan tugasnya sesuai dengan tanggung jawab yang diberikan kepadanya.

Suatu organisasi membutuhkan tenaga kerja untuk dapat beroperasi dan meningkatkan kualitas produk maupun jasa. Mengingat karyawan merupakan aset penting organisasi, maka banyak hal yang perlu diperhatikan terkait dengan peningkatan kinerja. Pada hakekatnya prestasi kerja merupakan kesuksesan seorang karyawan dalam melakukan suatu pekerjaan selama periode waktu tertentu didasarkan pada ketentuan yang telah ditetapkan. Campbell et al. menyatakan bahwa kinerja sebagai sesuatu yang tampak, dimana individu relevan dengan tujuan organisasi. Kinerja yang baik merupakan salah satu sasaran organisasi dalam mencapai produktivitas kerja yang tinggi. Tercapainya kinerja yang baik tidak terlepas dari kualitas sumber daya manusia yang baik pula.

Pada profesi auditor, kinerja berkaitan dengan kualitas audit. Tingkat kinerja yang rendah dapat meningkatkan potensi kesalahan, legal liability, dan kurangnya kredibilitas (Fisher, 2001). Skandal akuntansi yang pernah terjadi seperti Enron, mengakibatkan perlunya peningkatan kebutuhan akan kualitas kinerja audit pada tingkat individu maupun KAP. Sehingga, bagi KAP kinerja profesional merupakan konsekuensi penting pada kualitas audit dan eksistensi KAP. Bagi auditor sendiri, evaluasi kinerja penting untuk meningkatkan efektivitas, promosi dan masa jabatan.

\subsubsection{Faktor-faktor yang Mempengaruhi Kinerja}

Faktor-faktor yang mempengaruhi pencapaian kinerja menurut A.A Anwar Prabu Mangkunegara (2000:13) adalah faktor kemampuan (ability) dan faktor motivasi (motivation). Sedarmayanti (2004:177-178) pun setuju dengan pendapat Keith David bahwa beberapa faktor yang mempengaruhi pencapaian kinerja atau prestasi kerja adalah faktor kemampuan dan faktor motivasi.

Selain itu menurut Wahyuddin dan Djumino bahwa kinerja atau prestasi kerja seseorang merupakan gabungan dari tiga faktor, yaitu:

1. Kemampuan, peringai, dan minat.

2. Kejelasan dan penerimaan atas penjelasan seseorang pekerja.

3. Tingkat motivasi.

Menurut Simamora (1995:500), kinerja (performance) dipengaruhi oleh tiga faktor, yakni faktor individual, faktor psikologi, dan faktor organisasi. Sedangkan, Bernadin (1993:75) menjelaskan bahwa kinerja seseorang dapat diukur berdasarkan 6 kriteria yang dihasilkan dari pekerjaan yang bersangkutan. Keenam kriteria tersebut adalah:

a. Kualitas, merupakan tingkatan dimana hasil akhir yang dicapai mendekati sempurna dalam arti memenuhi tujuan yang diharapkan oleh perusahaan. 
b. Kuantitas, merupakan jumlah yang dihasilkan yang dinyatakan dalam istilah sejumlah unit kerja ataupun merupakan jumlah siklus aktivitas yang dihasilkan.

c. Ketepatan waktu, tingkat aktivitas diselesaikannya pekerjaan tersebut pada waktu awal yang diinginkan.

d. Efektifitas, merupakan tingkat pengetahuan sumber daya organisasi dimana dengan menaikkan keuntungan.

e. Kemandirian, karyawan dapat melakukan fungsi kerjanya tanpa meminta bantuan dari orang lain.

f. Komitmen, karyawan mempunyai tanggung jawab penuh terhadap pekerjaannya.

\subsection{Kantor Akuntan Publik}

Dalam KMK No. 423/KMK.06/2002 dijelaskan bahwa Kantor Akuntan Publik atau disingkat dengan KAP, adalah badan usaha yang telah mendapatkan izin dari Menteri sebagai wadah bagi Akuntan Publik dalam memberikan jasanya. Kantor Akuntan publik adalah organisasi yang diciptakan untuk memberikan jasa akuntansi profesional, termasuk audit. Biasanya didirikan sebagai kepemilikan pribadi atau persekutuan (Messier, Grover dan Prawitt, 2005:74). Pengertian Kantor Akuntan Publik (KAP) adalah suatu bentuk organisasi akuntan publik yang memperoleh izin sesuai dengan peraturan perundang-undangan yang berusaha dibidang pemberian jasa profesional dalam praktik akuntan publik (Sukrisno, 2004:272)

\subsubsection{Struktur Jabatan di Kantor Akuntan Publik}

Umumnya hirarki auditor dalam perikatan audit didalam kantor akuntan publik dibagi menjadi berikut ini (Mulyadi, 2002; 33-34):

a. Partner: menduduki jabatan tertinggi dalam perikatan audit; bertanggung jawab atas hubungan dengan klien; bertanggung jawab secara menyeluruh mengenai auditing. Partner menandatangani laporan audit dan management letter, dan bertanggung jawab terhadap penagihan fee audit dari klien.

b. Manajer: bertindak sebagai pengawas audit; bertugas untuk membantu auditor senior dalam merencanakan program audit dan waktu audit; me-review kertas kerja, laporan audit dan management letter. Biasanya manajer melakukan pengawasan terhadap pekerjaan beberapa auditor senior. Pekerjaan manajer tidak berada di kantor klien, melainkan di kantor auditor, dalam bentuk pengawasan terhadap pekerjaan yang dilaksanakan para auditor senior.

c. Auditor senior: bertugas untuk melaksanakan audit; bertanggung jawab untuk mengusahakan biaya audit dan waktu audit sesuai dengan rencana; bertugas untuk mengarahkan dan me-review pekerjaan auditor junior. Auditor senior biasanya akan menetap di kantor klien sepanjang prosedur audit dilaksanakan. Umumnya auditor senior melakukan audit terhadap satu objek pada saat tertentu.

d. Auditor junior: melaksanakan prosedur audit secara rinci; membuat kertas kerja untuk mendokumentasikan pekerjaan audit yang telah dilaksanakan. Pekerjaan ini biasanya dipegang oleh auditor yang baru saja menyelesaikan pendidikan formalnya di sekolah. Dalam melaksanakan pekerjaannya sebagai auditor junior, seorang auditor harus belajar secara rinci mengenai pekerjaan audit. Biasanya auditor junior melaksanakan audit di berbagai jenis perusahaan. Auditor junior harus banyak melakukan audit di lapangan dan di berbagai kota, sehingga auditor junior dapat memperoleh pengalaman banyak dalam menangani berbagai masalah audit. Auditor junior sering juga disebut dengan asisten auditor. 


\subsubsection{Jasa-jasa yang dihasilkan Akuntan Publik}

Profesi akuntan publik menghasilkan berbagai macam jasa bagi masyarakat, yang dapat digolongkan kedalam dua kelompok, Mulyadi (2002), antara lain :

a. Jasa Assurance: jasa profesional independen yang meningkatkan mutu informasi bagi pengambilan keputusan. Salah satu tipe jasa assurance yang disediakan oleh profesi akuntan publik adalah jasa atestasi. Atestasi adalah suatu pernyataan pendapat atau pertimbangan orang yang independen dan kompeten tentang apakah asersi suatu entitas sesuai, dalam semua hal yang material, dengan kriteria yang telah ditetapkan. Jasa atestasi profesi akuntan publik dapat dibagi lebih lanjut menjadi 4 jenis:

- Audit: jasa audit mencakup perolehan dan penilaian bukti yang mendasari laporan keuangan historis seatu entitas yang berisi asersi yang dibuat oleh manajemen entitas tersebut. Atas dasar audit yang dilaksanakan terhadap laporan keuangan historis suatu entitas, auditor menyatakan suatu pendapat mengenai apakah laporan keuangan tersebut menyajikan secara wajar, dalam semua hal yang material posisi keuangan dan hasil usaha entitas sesuai dengan prinsip akuntansi berterima umum. Dalam menghasilkan jasa audit ini, auditor memberikan keyakinan positif (possitive assurance) atas asersi yang dibuat oleh manajemen dalam laporan keuangan historis. Keyakinan (assurance) menunjukkan tingkat kepastian yang dicapai dan yang ingin disampaikan oleh auditor bahwa kesimpulannya yang dinyatakan dalam laporan adalah wajar. Tingkat keyakinan yang dapat dicapai oleh auditor ditentukan oleh hasil pengumpulan bukti.

- Pemeriksaan (examination): istilah pemeriksaan digunakan untuk jasa lain yang dihasilkan oleh profesi akuntan publik yang berupa pernyataan pendapat atas kesesuaian asersi yang dibuat oleh pihak lain dengan kriteria yang telah ditetapkan. Dalam menghasilkan jasa pemeriksaan, jasa akuntan publik memberikan keyakinan positif atas asersi yang dibuat oleh manajemen. Pemeriksaan oleh profesi akuntan publik selain terhadap laporan keuangan historis, seperti misalnya terhadap informasi keuangan prospektif.

- Review: jasa review terutama berupa permintaan keterangan dan prosedur analitik terhadap informasi keuangan suatu entitas dengan tujuan untuk memberikan keyakinan negatif atas asersi yang terkandung dalam informasi keuangan tersebut.

- Prosedur yang disepakati: jasa atestasi atas asersi manajemen dapat dilaksanakan oleh akuntan publik berdasarkan prosedur yang disepakati antara klien dengan akuntan publik. Untuk tipe jasa ini, akuntan publik dapat menerbitkan suatu "ringkasan temuan" atau suatu keyakinan negatif seperti yang dihasilkan dalam jasa review.

b. Jasa Non Assurance: adalah jasa yang dihasilkan oleh akuntan publik yang didalamnya ia tidak memberikan suatu pendapat, keyakinan negatif, ringkasan temuan, atau bentuk lain keyakinan. Jenis jasa non assurance yang dihasilkan oleh akuntan publik adalah:

- Jasa Kompilasi, akuntan publik melaksanakan berbagai jasa akuntansi kliennya, seperti pencatatan transaksi akuntansi bagi kliennya sampai dengan penyusunan laporan keuangan.

- Jasa Perpajakan, meliputi bantuan yang diberikan oleh akuntan publik kepada kliennya dalam pengisian surat pemberitahuan pajak tahunan (SPT) pajak penghasilan, perencanaan pajak, dan bertindak mewakili kliennya dalam menghadapi masalah perpajakan.

- Jasa Konsultasi, jasa ini meliputi bentuk dan bidang sesuai dengan kompetensi akuntan publik. Misalnya jasa konsultasi umum kepada pihak manajemen, perencanaan sistem dan implementasi sistem akuntansi, penyelenggaraan pendidikan 
dan pelatihan, pelaksanaan seleksi dan rekruitmen pegawai sampai memberikan jasa konsultasi lainnya.

\section{METODOLOGI PENELITIAN}

\subsection{Objek Penelitian}

Objek dalam penelitian ini adalah auditor di Kantor Akuntan Publik Bandar Lampung.

\section{Populasi}

Populasi dalam penelitian ini adalah para auditor yang bekerja pada KAP di Bandar Lampung. Dalam penelitian ini semua anggota populasi akan disebarkan kuisioner. Jumlah populasi dalam penelitian ini 27 auditor.

\section{Jenis dan Sumber Data}

Jenis data yang digunakan dalam penelitian ini adalah data primer. Sumber data berasal dari wawancara terstruktur (kuesioner) terhadap auditor

\section{Metode Pengumpulan Data}

Metode pengumpulan data yang dilakukan dalam penelitian ini adalah dengan menggunakan metode penyebaran kuesioner yang telah disusun secara terstuktur.

\subsection{Metode Analisis Data}

\section{Analisis Kualitatif}

Analisis kualitatif dalam penelitian ini digunakan untuk menilai hasil jawaban responden atas kuesioner yang telah disebar. Skala yang digunakan adalah skala likert dan interval.

1. Skala Likert untuk mengetahui tanggapan responden terhadap masing-masing butir intrumen indikator. Skala likert mempunyai kriteria penilaian 1-5, dengan demikian dapat dibuat kriteria penilaian sebagai berikut:

$\mathrm{I}=\frac{\mathrm{NT}-\mathrm{NR}}{\mathrm{K}}$

2. Interval mengetahui tanggapan responden terhadap variable penelitian. Skala interval mempunyai criteria penilaian 1-5, dengan menggunakan rumus sebagai berikut:

$\mathrm{I}=\frac{\mathrm{NT}-\mathrm{NR}}{\mathrm{K}}$

\section{Analisis Kuantitatif}

Sedangkan analisis menggunakan metode kuantitatif, diolah dengan menggunakan metode statistik. Analisis kuantitatif tersebut meliputi:

\section{Uji Validitas dan Reliabilitas}

Uji validitas digunakan untuk mengukur sah atau valid tidaknya kuesioner.

Uji reliabilitas digunakan untuk menguji reliabilitas kuesioner dengan menggunakan rumus koefisien Cronbach Alpha. 


\section{Uji Asumsi Klasik}

Uji asumsi klasik dalam penelitian ini terdiri dari :

a. Uji Normalitas

Uji normalitas dalam penelitian ini dilakukan melalui metode grafik. Selain dengan melihat grafik, normalitas data juga dengan melakukan uji statistik non-parametrik Kolmogorov-Smirnov.

b. Uji Multikolonieritas

Uji multikolinieritas bertujuan untuk menguji apakah variabel dalam model regresi ditemukan adanya korelasi antara variabel bebas (independen). Untuk mendeteksi ada tidaknya multikolinieritas didalam model regresi, digunakan: (1) nilai tolerance dan (2) Variance Inflation Factor (VIF).

\section{c. Uji Heteroskedastisitas}

Uji ini bertujuan untuk menguji apakah dalam model regresi terjadi ketidaksamaan variance dari satu residual pengamatan ke pengamatan yang lain (Ghozali, 2005).

\section{d. Metode Regresi Linier Berganda}

Analisis ini digunakan untuk mengetahui pengaruh variabel bebas terhadap variabel terikat, persamaan statistik analisis regresi berganda sebagai berikut:

$$
\begin{gathered}
\mathbf{Y}=\mathbf{a}+\boldsymbol{\beta 1 X 1}+\boldsymbol{\beta 2 X 2}+\boldsymbol{\beta 3 X 3}+\boldsymbol{\beta 4 X} \mathbf{4}+\mathbf{e}_{\mathbf{t}} \\
\text { Sumber: Sugiono }(2002: 347)
\end{gathered}
$$

Dimana:

$\mathrm{Y}=$ Variabel kinerja

$\mathrm{a}=$ Koefisien konstanta

$\mathrm{X}_{1}=$ Variabel pengalaman kerja

$\mathrm{X}_{2}=$ Variabel otonomi kerja

$\mathrm{X}_{3}=$ Variabel tekanan peran

$\beta=$ Koefisien regresi.

$\mathrm{e} \quad=$ Variabel pengganggu (error)

\section{Pengujian Hipotesis}

a. Uji Statistik F (uji secara simultan)

Uji $F$ ini digunakan untuk mengetahui ada tidaknya pengaruh secara bersama-sama (simultan) variabel-variabel independen (bebas) terhadap variabel dependen (terikat). Kriteria pengujian yang digunakan adalah:

Jika $\mathrm{F}_{\text {hitung }}>\mathrm{F}_{\text {tabel }}(\mathrm{n}-\mathrm{k}-1)$ maka Ho ditolak, Ha diterima.

Jika $F_{\text {hitung }}<F_{\text {tabel }}(n-k-1)$ maka Ho diterima , Ha ditolak.

b. Uji Statistik $\mathbf{t}$ (uji secara parsial)

Uji t digunakan untuk mengetahui pengaruh variabel $\mathrm{X}$ (pengalaman kerja, otonomi kerja dan tekanan peran) secara parsial terhadap variabel Y (kinerja). Ketentuan uji t sebagai berikut:

Bila $t_{\text {hitung }}>t_{\text {tabel}}$, maka Ho ditolak , Ha diterima

Bila $t_{\text {hitung }}<\mathrm{t}_{\text {tabe }} \mathrm{l}$, maka Ho diterima, Ha ditolak 


\section{HASIL DAN PEMBAHASAN}

\subsection{Analisis Kualitatif}

\section{Hasil Tanggapan Responden Menggunakan Skala Likert}

Berikut ini merupakan kriteria penilaian menggunakan skala likerts:

Skor Tertinggi - Skor Terendah

I

$$
\begin{gathered}
\text { Kategori } \\
\text { I } \quad=\frac{100 \%-20 \%}{5}=16
\end{gathered}
$$

$20 \%-35 \%=\quad$ Sangat Kurang Baik

$36 \%-51 \%=$ Kurang Baik

$52 \%-67 \%=$ Cukup Baik

$68 \%-83 \%=$ Baik

$84 \%-100 \%=$ Sangat Baik

Berdasarkan kriteria penilaian skala likert tersebut dengan variable-variabel yang terkait dapat disimpulkan bahwa :

a. Variable Pengalaman Kerja (X1) rata-rata mendapat kategori sangat baik dan baik.

b. Variable Otonomi Kerja (X2) auditor Kantor Akuntan Publik di Bandar Lampung secara keseluruhan dapat dikategorikan baik

c. Variable Tekanan Peran (X3) dapat disimpulkan bahwa tekanan peran auditor Kantor Akuntan Publik di Bandar Lampung dapat dikategorikan baik

d. Variable Kinerja dapat dilihat dari masing-masing indikator telah mendapat kategori sangat baik.

Hasil Tanggapan Responden Menggunakan Skala Interval

Skor Tertinggi - Skor Terendah

$$
\text { I }
$$

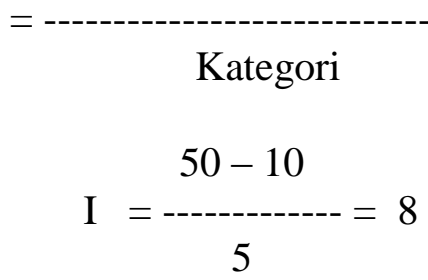

$10-17=\quad$ Sangat Kurang Baik

$18-25=$ Kurang Baik

$26-33=$ Cukup Baik

$34-41=$ Baik

$42-50=$ Sangat Baik

Berdasarkan kriteria penilaian skala Interval tersebut dengan variable-variabel yang terkait dapat disimpulkan bahwa :

a. Variable Pengalaman Kerja (X1) rata-rata mendapat kriteria baik

b. Variable Otonomi Kerja (X2) sebagian responden besar dapat dikategorikan sangat baik.

c. Variable Tekanan Peran (X3) sebagian besar dapat dikategorikan baik.

d. Variabel Kinerja (Y) dapat dikategorikan sangat baik. 


\subsection{Analisis Kuantitatif}

\section{Uji Validitas dan Reliabilitas}

Tabel 1 Hasil Perhitungan Validitas

\begin{tabular}{|c|c|c|c|c|}
\hline $\begin{array}{c}\text { Perta } \\
\text { nyaan }\end{array}$ & $\left(\mathrm{X}_{1}\right)$ & $\left(\mathrm{X}_{2}\right)$ & $\left(\mathrm{X}_{3}\right)$ & $(\mathrm{Y})$ \\
\hline 1 & 0,458 & 0,585 & 0,486 & 0,718 \\
\hline 2 & 0,634 & 0,560 & 0,620 & 0,529 \\
\hline 3 & 0,518 & 0,840 & 0,765 & 0,565 \\
\hline 4 & 0,545 & 0,732 & 0,527 & 0,680 \\
\hline 5 & 0,555 & 0,655 & 0,678 & 0,765 \\
\hline 6 & 0,567 & 0,614 & 0,630 & 0,750 \\
\hline 7 & 0,444 & 0,429 & 0,552 & 0,556 \\
\hline 8 & 0,582 & 0,522 & 0,563 & 0,416 \\
\hline 9 & 0,546 & 0,608 & 0,407 & 0,411 \\
\hline 10 & 0,666 & 0,726 & 0,389 & 0,383 \\
\hline
\end{tabular}

Sumber: Data Lampiran Hasil Output SPSS, 2013

Berdasarkan pengujian tersebut maka semua pernyataan pada masing-masing variabel dinyatakan memiliki tingkat validitas yang sudah cukup baik. Hal ini dapat dilihat dari nilai $r_{\text {hitung }}$ lebih besar dari nilai $r_{\text {tabel }}(0,381)$ dengan tingkat kesalahan $(\alpha=5 \%)$.

Tabel 2 Hasil Perhitungan Reliabilitas

\begin{tabular}{|l|c|c|c|}
\hline \multicolumn{1}{|c|}{ Variabel } & $\begin{array}{c}\text { Cronbach } \\
\text { Alpha }\end{array}$ & Batas Reliabilitas & Keterangan \\
\hline (X1) & 0,843 & 0,60 & Reliabel \\
\hline (X2) & 0,881 & 0,60 & Reliabel \\
\hline (X3) & 0,850 & 0,60 & Reliabel \\
\hline$(Y)$ & 0,856 & 0,60 & Reliabel \\
\hline
\end{tabular}

Sumber: Data Lampiran Hasil Output SPSS, 2013.

Berdasarkan hasil pengujian reliabilitas menunjukkan bahwa nilai koefisien Alpha Cronbach menghasilkan Alpha lebih besar dari 0,60. Dengan demikian dapat disimpulkan bahwa alat ukur yang digunakan dalam penelitian ini adalah reliabel. 


\title{
Uji Asumsi Klasik
}

a. Uji Normalitas

\author{
Gambar 1. Hasil Uji Normalitas
}

Normal P.P Plot of Regression Standardized Residual

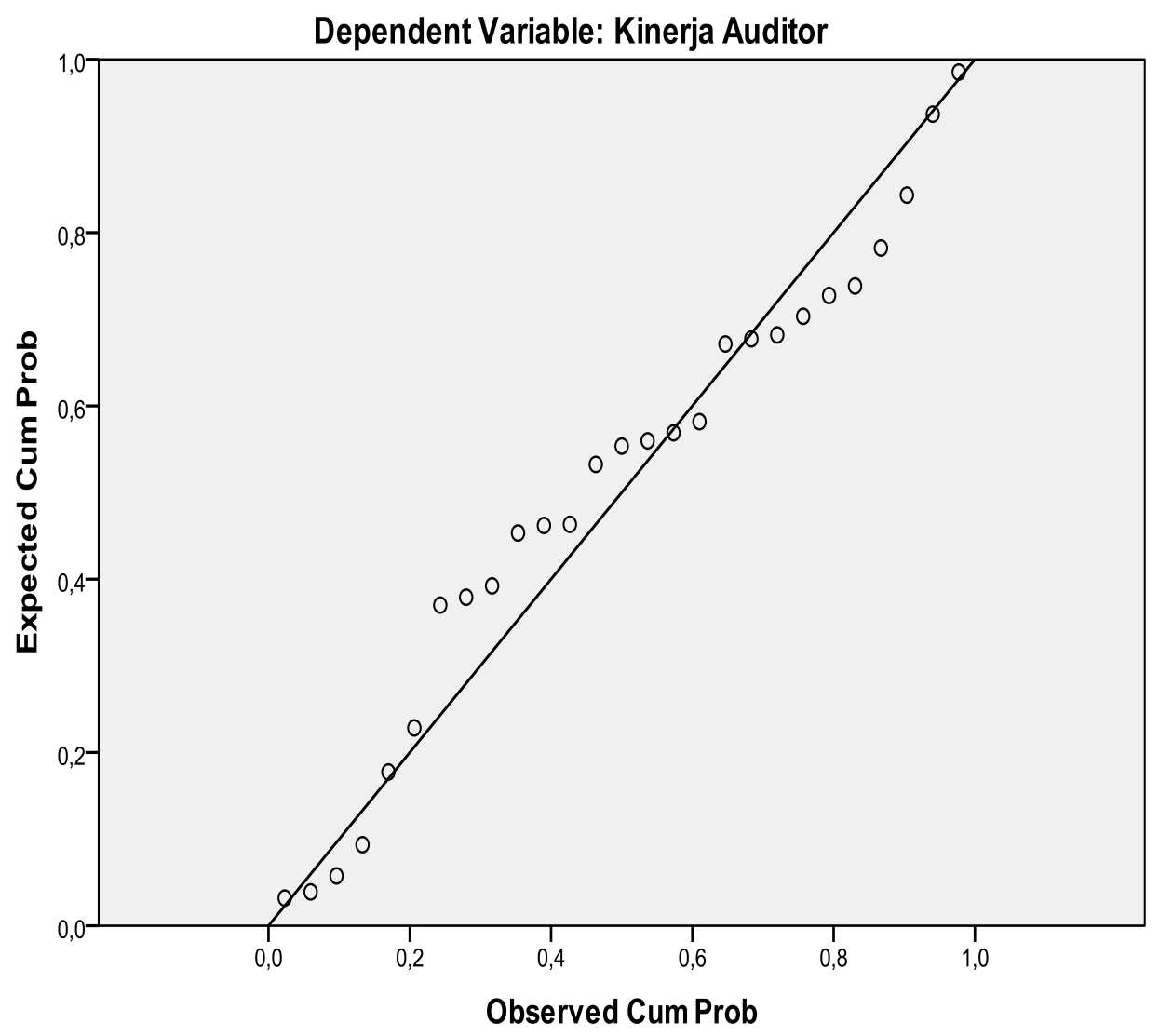

Sumber: Data Hasil Output SPSS, 2013

Pada gambar 1 dapat dilihat bahwa pada grafik normal probability plot of regresison standardized menunjukan pola grafik yang normal. Hal ini terlihat dari titik-titik yang menyebar di sekitar garis diagonal dan penyebarannya mengikuti garis diagonal.

Tabel 2 Kolmoggorov- Smirnov

One-Sample Kolmogorov-Smirnov Test

\begin{tabular}{|ll|r|}
\hline & & Unstandardized Residual \\
\hline Normal Parameters & & 27 \\
& Mean &, 0000000 \\
Most Extreme Differences & Std. Deviation & 1,09025572 \\
& Absolute &, 140 \\
& Positive &, 100 \\
Kolmogorov-Smirnov Z & Negative &,- 140 \\
Asymp. Sig. (2-tailed) & &, 727 \\
\end{tabular}

a. Test distribution is Normal.

b. Calculated from data. 
Sedangkan hasil pengujian menggunakan uji statistik non-parametrik KolmogorovSmirnov menunjukkan bahwa p-value 0,665 lebih besar dari 0,05, maka dapat disimpulkan data berdistrubusi normal.

b. Uji Multikolonieritas

Tabel 3 Uji Multikolonieritas

Coefficients $^{\mathrm{a}}$

\begin{tabular}{|c|c|c|c|}
\hline \multirow{2}{*}{\multicolumn{2}{|c|}{ Model }} & \multicolumn{2}{|c|}{ Collinearity Statistics } \\
\hline & & Tolerance & VIF \\
\hline \multirow[t]{4}{*}{1} & (Constant) & & \\
\hline & Pengalaman Kerja & ,272 & 3,671 \\
\hline & Otonomi kerja & 294 & 3,406 \\
\hline & Tekanan Peran & ,454 & 2,204 \\
\hline
\end{tabular}

a. Dependent Variable: Kinerja Auditor

\section{Sumber: Data Lampiran hasil Output SPSS, 2013}

Berdasarkan ouput diatas dapat dilihat bahwa model regresi tidak mengalami gangguan multikolonieritas. Hal ini tampak pada nilai tolerance masing-masing variabel bebas yang lebih besar dari 0,1 . Hasil penghitungan VIF juga menunjukan bahwa nilai VIF masing-masing variabel bebas kurang dari 10.

\section{c. Uji Heteroskedastisitas}

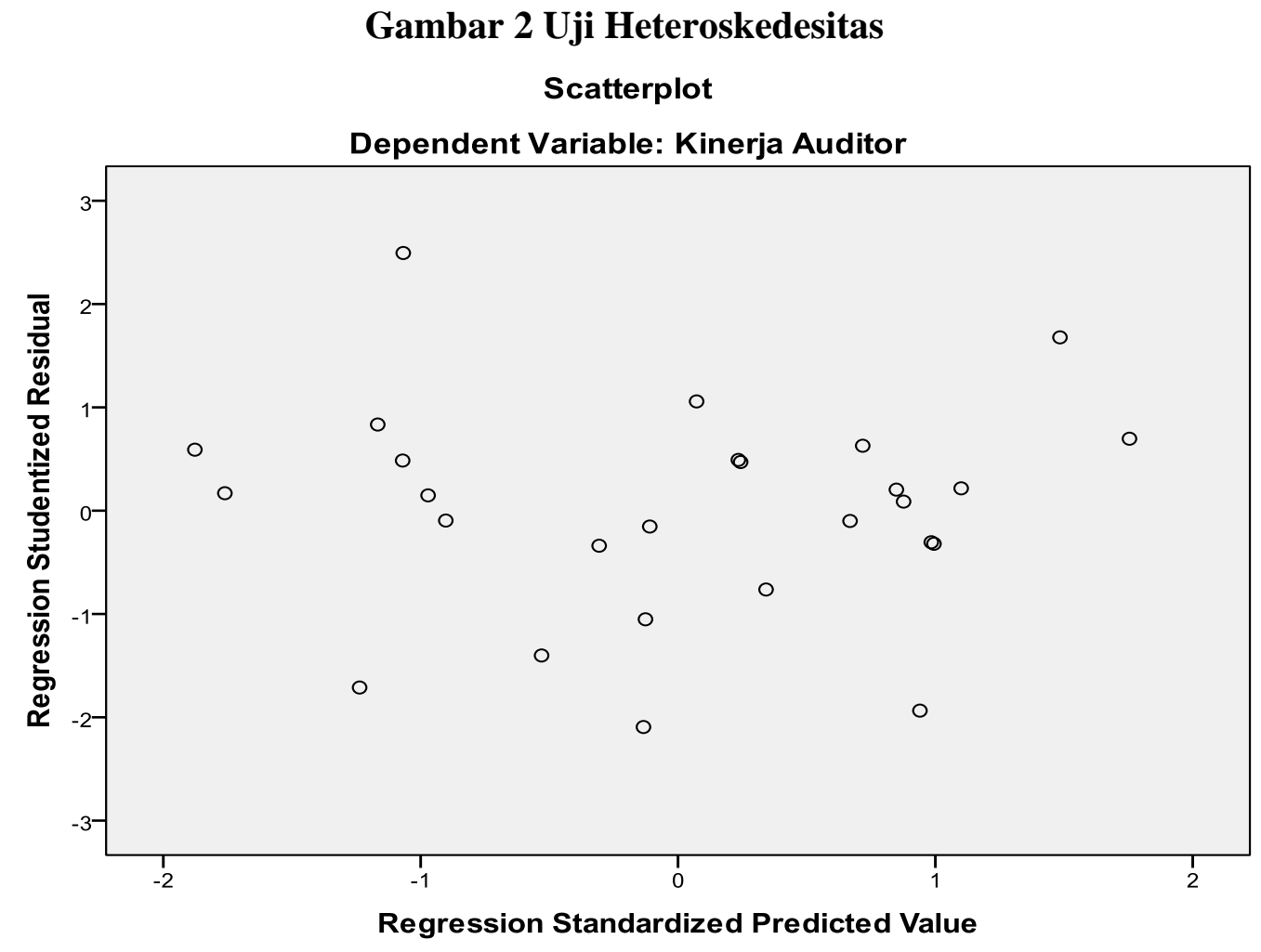

Sumber: Data Hasil Output SPSS, 2013 


\subsection{Analisis Regresi Linier Berganda Coefficients ${ }^{\mathrm{a}}$}

Tabel 4 Regresi Linier Berganda

\begin{tabular}{|c|c|c|c|c|c|}
\hline \multirow[t]{2}{*}{ Model } & \multicolumn{2}{|c|}{$\begin{array}{c}\text { Unstandardized } \\
\text { Coefficients }\end{array}$} & \multirow{2}{*}{$\begin{array}{c}\begin{array}{c}\text { Standardized } \\
\text { Coefficients }\end{array} \\
\text { Beta }\end{array}$} & \multirow[t]{2}{*}{$\mathrm{t}$} & \multirow[t]{2}{*}{ Sig. } \\
\hline & $\mathrm{B}$ & Std. Error & & & \\
\hline 1 (Constant & 24,912 & 4,875 & & 5,110 & ,000 \\
\hline $\mathrm{X} 1$ & , 195 & ,086 & 249 & 2,271 & 033 \\
\hline $\mathrm{X} 2$ & ,425 & ,086 & ,521 & 4,939 & ,000 \\
\hline X3 &,- 209 & ,064 &,- 277 & $-3,263$ & ,003 \\
\hline
\end{tabular}

Dari hasil uji regresi tersebut, maka dapat dibentuk persamaan regresi linier berganda sebagai berikut:

$\mathrm{Y}=24,912+0,195 \mathrm{X}_{1}+0,425 \mathrm{X}_{2}-0,209 \mathrm{X}_{3}$

Persamaan tersebut mengandung arti:

a. Koefisien regresi variabel pengalaman kerja $\left(\mathrm{X}_{1}\right)$ bertanda positif $(+)$, hal ini menunjukan terdapat suatu kondisi yang searah yaitu apabila variabel $\mathrm{X}_{1}$ meningkat $0,01(1 \%)$, maka variabel kinerja auditor (Y) akan meningkat sebesar 0,195 (19,5\%).

b. Koefisien regresi variabel otonomi kerja $\left(\mathrm{X}_{2}\right)$ bertanda positif $(+)$, hal ini menunjukan terdapat suatu kondisi yang searah yaitu apabila variabel $X_{2}$ meningkat $0,01(1 \%)$, maka variabel kinerja auditor (Y) akan bertambah sebesar 0,425 (42,5\%).

c. Koefisien regresi variabel tekanan peran $\left(\mathrm{X}_{3}\right)$ bertanda negatif $(-)$, hal ini menunjukan terdapat suatu kondisi yang berlawanan arah yaitu apabila variabel $\mathrm{X}_{3}$ meningkat 0,01 (1\%), maka variabel kinerja auditor (Y) akan menurun sebesar 0,209 (20,9\%).

\subsection{Analisis Korelasi Dan Pengaruh Antara Variabel Dependen Dan Independen}

Tabel 5 Korelasi

Model Summary ${ }^{b}$

\begin{tabular}{|r|r|r|r|r|}
\hline Model & \multicolumn{1}{|c|}{$\mathrm{R}$} & R Square & Adjusted R Square & $\begin{array}{c}\text { Std. Error of the } \\
\text { Estimate }\end{array}$ \\
\hline 1 &, $962^{\mathrm{a}}$ &, 925 &, 915 & 1,159 \\
\hline
\end{tabular}

a. Predictors: (Constant), Tekanan Peran, Otonomi kerja, Pengalaman Kerja

b. Dependent Variable: Kinerja Auditor

Dari hasil perhitungan menggunakan SPSS, didapatkan besarnya korelasi antara variabel pengalaman kerja $\left(\mathrm{X}_{1}\right)$, otonomi kerja $\left(\mathrm{X}_{2}\right)$, tekanan peran $\left(\mathrm{X}_{3}\right)$ dengan variabel terikat kinerja auditor (Y) adalah sebesar 0,962 . 
Uji Hipotesis

Uji Statistik F (Uji Simultan)

Tabel 6 Uji Annova

ANOVA ${ }^{b}$

\begin{tabular}{|ll|r|r|r|r|c|}
\hline Model & Sum of Squares & df & Mean Square & F & Sig. \\
\hline $1 \quad$ Regression & 379,762 & 3 & 126,587 & 94,208 &, 000 \\
Residual & 30,905 & 23 & 1,344 & & \\
Total & 410,667 & 26 & & & \\
\hline
\end{tabular}

a. Predictors: (Constant), Tekanan Peran, Otonomi kerja, Pengalaman Kerja

b. Dependent Variable: Kinerja Auditor

Sumber: Data Lampiran hasil Output SPSS, 2013

Dari hasil perhitungan data program SPSS tersebut di atas diperoleh $\mathrm{F}_{\text {hitung }}$ sebesar 94,208 dengan $\mathrm{F}_{\text {tabel }(\mathrm{k}-1, \mathrm{n}-\mathrm{k})}$ sebesar 3,40. Dalam hal ini, $\mathrm{F}_{\text {hitung }}>\mathrm{F}_{\text {tabel }}$ maka $\mathrm{H}_{0}$ ditolak dan $\mathrm{H}_{1}$ diterima, yang berarti bahwa pengalaman kerja, otonomi kerja, dan tekanan peran secara bersama-sama (simultan) berpengaruh secara positif dan signifikan terhadap kinerja auditor.

\section{Uji Statistik t (Uji Parsial)}

Tabel 7 Uji Statistik t

\begin{tabular}{|l|r|r|r|r|r|}
\hline Model & \multicolumn{2}{|c|}{$\begin{array}{c}\text { Unstandardized } \\
\text { Coefficients }\end{array}$} & \multicolumn{2}{|c|}{$\begin{array}{c}\text { Standardized } \\
\text { Coefficients }\end{array}$} & \multirow{2}{*}{ Sig. } \\
\cline { 2 - 4 } \cline { 6 - 7 } & \multicolumn{1}{|c|}{ B } & Std. Error & Beta & \multicolumn{1}{c|}{$\mathrm{t}$} & \\
\hline 1 (Constant) & 24,912 & 4,875 & & 5,110 &, 000 \\
X1 &, 195 &, 086 &, 249 & 2,271 &, 033 \\
X2 &, 425 &, 086 &, 521 & 4,939 &, 000 \\
X3 &,- 209 &, 064 &,- 277 & $-3,263$ &, 003 \\
\hline
\end{tabular}

Untuk menghitung besarnya angka $t_{\text {tabel }}$ dengan taraf signifikan $95 \%$ atau $\alpha$ sebesar 0,05 dengan derajat kebebasan $(\mathrm{dk})=\mathrm{n}-\mathrm{k}-1=27-3-1=23$, maka nilai $\mathrm{t}_{\text {tabel }}=1,714$.

Berdasarkan hasil perhitungan data program SPSS tersebut di atas diperoleh:

a. Dari hasil tersebut ternyata nilai $t_{\text {hitung }}>t_{\text {tabel }}$ sehingga dapat disimpulkan bahwa $\mathrm{H}_{0}$ ditolak dan $\mathrm{H}_{1}$ diterima yang berarti terdapat pengaruh yang positif dan signifikan dari pengalaman kerja terhadap kinerja auditor.

b. Dari hasil tersebut ternyata nilai $t_{\text {hitung }}>t_{\text {tabel }}$ sehingga dapat disimpulkan bahwa $\mathrm{H}_{0}$ ditolak dan $\mathrm{H}_{1}$ diterima yang berarti terdapat pengaruh yang positif dan signifikan dari otonomi kerja terhadap kinerja auditor.

c. Dari hasil tersebut ternyata nilai $t_{\text {hitung }}<t_{\text {tabel }}$ sehingga dapat disimpulkan bahwa $\mathrm{H}_{0}$ diterima dan $\mathrm{H}_{1}$ ditolak yang berarti tidak terdapat pengaruh yang positif dan signifikan dari tekanan peran terhadap kinerja auditor. 


\section{KESIMPULAN DAN SARAN}

\subsection{Kesimpulan}

Berdasarkan analisis data dalam pembahasan yang telah dilakukan, maka penulis menarik kesimpulan bahwa pengalaman kerja, otonomi kerja, dan tekanan peran memiliki pengaruh terhadap kinerja auditor, hal ini didukung oleh:

1. Berdasarkan hasil analisis deskripsi skor jumlah responden tentang pengalaman kerja otonomi kerja, dan tekanan peran sudah baik, dan kinerja yang dimiliki pun sudah sangat baik.

2. Berdasarkan hasil analisis deskripsi frekuensi jawaban responden tentang pengalaman kerja dan tekanan peran sudah baik, artinya auditor memiliki pengalaman kerja yang baik serta mampumengatasi tekanan peran dengan baik. Otonomi kerja yang dimiliki sangat baik sehingga membuat kinerja yang dihasilkan auditor pun menjadi sangat baik.

3. Berdasarkan hasil analisis regresi linier berganda, menunjukkan tanda positif antara variabel $\mathrm{X}_{1}, \mathrm{X}_{2}$ dan $\mathrm{Y}$. Hal ini berarti adanya hubungan yang searah yaitu peningkatan variabel baik $X_{1}$ maupun $X_{2}$ akan menyebabkan peningkatan variabel $Y$. Namun tanda negatif pada variabel $X_{3}$ mengakibatkan hubungan yang berlawanan arah, dimana kenaikan pada variabel $\mathrm{X}_{3}$ akan menyebabkan penurunan bagi variabel $\mathrm{Y}$.

4. Berdasarkan pengujian hipotesis secara simultan, ternyata diperoleh $F_{\text {hitung }}(94,208)>$ $\mathrm{F}_{\text {tabel }}(3,42)$ maka $\mathrm{H}_{0}$ ditolak dan $\mathrm{H}_{1}$ diterima, yang berarti bahwa semua variabel independen $\left(\mathrm{X}_{1}, \mathrm{X}_{2}, \mathrm{X}_{3}\right)$ secara bersama-sama (simultan) berpengaruh terhadap variabel dependen (Y).

5. Berdasarkan pengujian hipotesis secara parsial ternyata variabel tekanan peran tidak berpengaruh terhadap kinerja, sedangkan variabel pengalaman kerja dan otonomi kerja berpengaruh terhadap kinerja.

\subsection{Saran}

Berdasarkan kesimpulan di atas maka penulis memberikan saran sebagai berikut:

1. Penelitian ini menemukan bukti bahwa tekanan peran akan mempengaruhi kinerja auditor. Oleh karena itu, tepat bagi KAP untuk mempertimbangkan penambahan jumlah auditor sehingga auditor tidak akan berada pada kondisi kelebihan beban pekerjaan yang akan berdampak pada menurunnya kinerja serta berikan penyampaian informasi yang jelas dan tepat agar tidak terjadi keambiguitasan peran.

2. Perlu ditingkatkannya kualitas dan kuantitas kerja, ketepatan waktu, efektivitas, kemandirian dan komitmen dalam diri dengan beberapa cara diantaranya pekerjaan diselesaikan dengan hasil yang baik sesuai target yang telah ditentukan, auditor selalu berpedoman pada standar auditing dalam menjalankan tugas-tugasnya, pekerjaan yang dibebankan diselesaikan dengan tepat waktu dan auditor harus memiliki komitmen dalam setiap melakukan pengauditan.

3. Untuk penelitian selanjutnya, disarankan untuk menambah variabel bebas yang lain (seperti: pelatihan, kompetensi, intelektual), melakukan penyempurnaan kuesioner ini, serta melakukan pemilihan waktu yang tepat ketika menyebar kuesioner. 
DAFTAR PUSTAKA

“Akuntan Publik". Wikipedia bahasa Indonesia, ensiklopedia bebas. January 20, 2013. http://www. id.wikipedia.org.

Amilin dan Rosita. 2008. Analisis Dampak Karakteristik Personal, Pengalaman Audit, dan Independensi Akuntan Publik Terhadap Penerapan Etika Akuntan Publik dan Implikasinya Terhadap Kualitas Audit. Tesis Bandung: Program Pascasarjana Unpad (tidak dipublikasikan).

Arikunto, Suharsimi, 2006. Prosedur Penelitian: Suatu Pendekatan Praktik, Edisi Revisi, Cetakan Ketigabelas, Penerbit Rineka Cipta, Jakarta.

Astriana, Novika. 2010. Analisis Faktor-Faktor Yang Mempengaruhi Job Performance Auditor Pada Kantor Akuntan Publik Di Semarang. Makalah Semarang: Universitas Diponegoro (tidak dipublikasikan).

Bernardin dan Russel. 1993. Human Resource Management: An Experiental Apporoach. $8^{\text {th }}$ ed. (International Edition).

Campbell, C. 1998. Psychological climate: Relevance for Sales Manajer and Impact on Concequent Job Satisfaction. Journal of Marketing Theory and Practice; Winter 1998, hlm. 27-37.

Fisher, R.T. 2001. Role Stress, the Tipe A Behavior Pattern, and External Auditor Job Satisfaction and Performance. Behavioral Research In Accounting, Vol. 13. 143.

Ghozali, Imam. 2005. Aplikasi Multivariate dengan Program SPSS. Semarang: Badan Penerbit Universitas Diponegoro.

Herliansyah, Y dan Ilyas, M. 2006. Pengaruh Pengalaman Auditor Terhadap Penggunaan Bukti Tidak Relevan Dalam Auditor Judgment. Simposium Nasional Akuntansi IX.

Indriantoro, N. dan S. Bambang. 2002. Metodologi Penelitian Bisnis untuk Akuntansi dan Manajemen.Yogyakarta: BPFE.

Kalbers L.P., and Cenker W.J. 2008. The Impact of Exercised Responsibility, Experience, Autnomy and Role Ambiguity on Job Performance in Public Accounting. Journal of Manajerial Issues, Vol XX, hlm. 327-347.

Morgeson, F.P., K. Delaney-Klinger and M. Hemingway. 2005. The importance of job autonomy, cognitive ability, and job-related skill for predicting role breadth and job performance. Journal of Applied Psychology, 90:2, hlm. 399-406.

Pearson, A., J.M. Pearson, C. Griffin. 2009. Innovating with Technology: The Impact of Overload, Autonomy, and Work and Family Conflict. Journal of Information Technology Theory and Application (JITTA), 9:4, 2009,hlm. 41-65.

Putri dan Bandi, (2002). Pengaruh Pengalaman dan Pelatihan pada Struktur Pengetahuan Auditor Tentang Kekeliruan. Simposium Nasional Akuntansi V. Semarang. 
Quinones, M.A., Ford, J.K., and Teachout M.S. (1995). The Reliationship Between Work Experience and Job Performance: A Conceptual and Meta-Analitic Review. Personel Psychology.

Robbins. Stephen P., dan Timothy A.Judge. 2008. Essentials of th Organizational Behavior. $9^{\text {th }}$ edition. New Jersey: Pearson Education.

Sanusi, Anwar. 2012. Metodologi Penelitian Bisnis. Jakarta: Salemba Empat.

Setiawan, Ivan Aris dan Imam Ghozali. 2006. Akuntansi Keperilakuan : Konsep dan Kajian Empiris Perilaku Akuntan. BPFE UNDIP. Semarang.

Siagian, S.P. 2008. Teori dan Praktek Kepemimpinan. Jakarta: Rineka Cipta

Siegel, Gary and Marconi, Helena R. 1999. Behavioral Accounting. South Western Publishing Co. Cincinnati.Ohio.

Siguaw, J.A., Brown, G., and Widing, R.E. 1994. The Influence of the Market orientation of the Firm on Sales Force Behavior and Attitudes. Journal of marketing research, 31: 63-74.

Simamora, H. 2002. Auditing. Jilid 1. UPP AMP YKPN. Yogyakarta.

Singgih Santoso. 2002. Mastering SPSS Versi 19. Jakarta: PT Elex Media Komputindo.

Susetyo, Budi. 2009. Pengaruh Pengalaman Audit Terhadap Pertimbangan Auditor Dengan Kredibilitas Klien Sebagai Variabel Moderating. Tesis Semarang: Universitas Diponegoro (tidak dipublikasikan).

Suwandi, dan Nor Indriantoro. 1999. Pengujian Model Turnover Pasewark dan strawser: Studi Empiris pada Lingkungan KAP. Jurnal Riset Akuntansi Indonesia, Vol 2, Edisi Juli 1999 : 173-195.

Syukur, Sukriah. 2009. Pengaruh Pengalaman Kerja, Independensi, Obyektifitas, Integritas dan Kompetensi Terhadap Kualitas Hasil Pemeriksaan. SNA XII.

Tai, W.T., and Liu, S.C. 2007. An Ivestigation of The Influences of Job Autonomy and Neuroticism on Job Stressor-Strain Relations. Social Behavior and Personality. 35, 1007-1020.

Undang-Undang Nomor 5 Tahun 2011 tentang akuntan publik. 